DOI: https://doi.org/10.24144/2409-6857.2018.1(51).457-462

УДК 65.015.2:657.222

Сокольська Р.Б., Зелікман В.Д., Фандєєва І.А.

\title{
МЕТОДИЧНИЙ ПІДХІД ДО ВИЗНАЧЕННЯ ТРУДОМІСТКОСТІ ОБЛІКОВИХ РОБІТ
}

\begin{abstract}
В роботі досліджуються питання оцінки рівня трудомісткості облікових робіт на підприємстві. Розглянуті методи визначення трудовитрат на облікові роботи. Обтрунтовано використання методу оцінки трудових витрат облікових працівників, який засновано на розподіленні загальної задачі визначення трудовитрат на фіксовану та динамічну складові. Розроблено систему коригуючих коефіиієнтів, які доцільно використовувати при оцінияі динамічної складової трудовитрат. Запропонований узагальнюючий інтегральний коефічієнт впливу динамічної складової на трудомісткість облікових робіт.
\end{abstract}

Ключові слова: трудомісткість, облікові роботи, організація праці, оцінка трудовитрат, нормування часу, коригуючі коефічієнти.

Постановка проблеми. Організація облікового процесу здійснюється за рядом параметрів. Під параметрами організації обліку розуміються такі характеристики облікового процесу, які дозволяють створити та вдосконалити систему, в якій цей процес здійснюється [1]. Зазначені характеристики можуть бути розподілені на дві групи: технологічні та трудові [1]. Технологічні параметри відносяться до технології обліку, а саме процесів отримання, обробки та передачі інформації, а трудові відносяться до процесів організації праці робітників облікового апарату, розподілу обов'язків та повноважень і таке інше.

Визначення параметрів організації облікового процесу здійснюється відповідно до об'єктів організації фінансового обліку:

а) робітників облікового апарату;

б) інформаційних потоків в системі фінансового обліку [1].

Якщо питанням організації інформаційних потоків у сучасних умовах діяльності вітчизняних підприємств приділяється багато уваги (оптимізація якісних та кількісних характеристик інформації, складу та руху документів, удосконалення системи документообігу та ін. $[2,3])$, то питання організації праці робітників облікового апарату, як правило, залишаються поза увагою.

Одним 3 найважливіших технологічних

(c) Сокольська Рената Борисівна, к.е.н., доцент, доцент кафедри обліку i аудиту, Національна металургійна академія України, м. Дніпро

Зелікман Владислав Давидович, к.т.н, доцент, зав. кафедри обліку і аудиту, Національна металургійна академія України, м. Дніпро

Фандєєва Ірина Андріївна, магістрант кафедри обліку і аудиту, Національна металургійна академія України, м. Дніпро, тел.: 0562474451, email: rena@email.ua параметрів організації праці для робітників облікового апарату є трудомісткість облікових робіт, від якої залежать усі інші важливі параметри, включаючи кількість працівників. Ці питання набувають особливої актуальності при реформування системи обліку на підприємстві, зокрема при виділенні окремих підсистем фінансового та управлінського обліку.

Аналіз останніх досліджень і публікацій. Визначення трудомісткості робіт $є$ важливим завданням управління персоналом підприємства. Вагомий внесок у розвиток теоретичних аспектів вдосконалення методів визначення трудомісткості при нормуванні праці внесли такі вітчизняні та зарубіжні вчені, як Багрова I.B., Балабанова Л.В., Гайдай І.Ю., Горбатюк К.В., Джоші O.I., Дзюба С.Г., Єрьоменко В.О., Сисун Г.Г. та інші [4 - 6]. Питаннями організації праці облікових робітників займалися Бутинець Ф.Ф., Войналович О.П., Лень В.С., Завгородній В.П., Івахненков С.В., Островерха P.Е., Сльозко Т.М., Сопко В.В., Шмигель А.Д. та інші [7 - 9]. Однак у цих роботах недостатньо уваги приділено методичному підходу до визначення трудомісткості облікових робіт, який враховував би їх специфічні особливості.

Формулювання цілей статті. Метою даної роботи $\epsilon$ розробка методичного підходу до визначення трудомісткості облікових робіт 3 урахуванням специфічних особливостей облікового процесу в умовах реформування системи обліку на підприємстві.

Опис основного матеріалу дослідження. В теорії управління під трудомісткістю розуміється економічний показник, який характеризує витрати робочого часу на виробництво одиниці продукції або на виконання конкретної технологічній операції [4]. Трудомісткість $\epsilon$ одним 3 показників продуктивності праці та обчислюється шляхом ділення витраченого часу 
на кількість виробленої продукції або обсяг виконаних робіт [6]. Однак 3 визначенням трудомісткості виникає суттєва проблема, коли має бути здійснена оцінка обсягів виконаних робіт, які не мають кількісного виміру. Саме до таких робіт і відносяться облікові роботи.

Традиційно трудомісткість облікової роботи визначається за одним 3 трьох методів: експертним методом, дослідницько-статистичним або розрахунково-аналітичним [10]. Але за останні роки розроблено багато різних моделей кількісної оцінки трудовитрат [5]. При цьому у загальному вигляді усі методи оцінки трудовитрат можна розділити на дві групи:

1) методи мікрооцінки - методи, які засновані на точному знанні всіх складових роботи, передбачають побудову структури роботи, розбиття роботи на складові й оцінку трудомісткості кожної складової;

2) методи макрооцінки - методи, які засновані на функціональних вимогах та/або інших визначених якостях кінцевого продукту [10].

3 точки зору використання математичного апарату всі методи оцінки поділяються на алгоритмічні та неалгоритмічні.

До алгоритмічних методів відноситься методи оцінки трудовитрат, засновані на використанні економіко-математичних моделей.

Математичний апарат алгоритмічних методів різноманітний. Усі математичні моделі визначають трудовитрати як функцію, залежну від багатьох змінних, відповідних факторів, що впливають на трудовитрати. Тому різноманітність алгоритмічних методів, обумовлена двома аспектами: вибором факторів і формою функції. Залежно від цього виділяють три основні групи моделей: лінійні, мультиплікативні, статичні [10].

Лінійні моделі не виправдали себе i піддавалися об'єктивній критиці, оскільки зв'язок між факторами i трудозатратами нелінійний, та трудовитрати змінюються експоненціально. Мультиплікативні моделі складні в калібруванні і не знайшли широкого практичного застосування. Найбільш відомий статичний метод СОСОМ (базова модель створена в 1981 році Б. Боєм [10]).

Головною проблемою методів оцінки трудовитрат $\epsilon$ складність їх адаптації до конкретних умов (калібрування коефіцієнтів моделі). У кожному випадку має місце своя специфіка діяльності. Узагальнюючі моделі, такі як СОСОМ, не можуть повністю врахувати цієї специфіки [10].

До неалгоритмічних методів відноситься:

1) оцінка за аналогією - метод, згідно з яким оцінку трудовитрат отримують шляхом порівняння 3 аналогічною ситуацією [10]; перевагою такої оцінки $є$ те, що вона заснована на фактичних даних, недоліком - некоректність оцінок, що часто виникає, або неможливість застосування цього методу у зв'язку 3 відсутністю аналогій;

2) експертна оцінка - метод, згідно з яким оцінку трудовитрат отримують шляхом врахування думки кількох експертів та їх досліджень [10]; цей метод широко застосовується, достатньо розроблена методика узгодження оцінок експертів, але $\epsilon$ ряд проблем, пов'язаних 3 використанням цього методу, а саме: підстави для отримання оцінки $є$ неявними; важко знаходити висококваліфікованих експертів; експертна оцінка виходить адекватною, якщо попередній досвід експертів відповідає особливостям оцінюваного об'єкту; політика керівництва, спрямована на скорочення витрат, як правило, ставить під сумнів реальний досвід і вносить частку «сліпого оптимізму»;

3) оцінка, заснована на принципі Паркінсона: «робота розширюється, заповнюючи весь доступний обсяг» - метод, згідно 3 яким трудовитрати визначаються не за рахунок ї об'єктивної оцінки, а за доступними ресурсами [10]; перевагою цього методу $є$ простота, але такий розрахунок трудовитрат може привести до зайнятості співробітників в позаурочний час та неякісного виконання роботи або, навпаки, до недостатньої завантаженості співробітників;

4) «ціна перемоги» - метод, згідно 3 яким оцінка трудовитрат проводиться таким чином, щоб вона виявилася найвигіднішою для замовника [10]; основою для такої оцінки є бюджет замовника; перевагами цього методу $є$ підвищення ймовірності отримання замовлень при наданні аутсорсингових послуг 3 ведення обліку, недоліки аналогічні недолікам оцінки, заснованої на принципі Паркінсона.

Однак жоден 3 розглянутих методів визначення трудомісткості робіт (як алгоритмічних, так i неалгоритмічних) не дозволяє врахувати специфіку облікових робіт, зокрема залежність їх трудомісткості від динаміки змін факторів, які впливають (як правило, негативно) на діяльність працівників облікового апарату - реформування законодавства, трансформація організаційної структури управління підприємством тощо.

Для урахування вказаних факторів пропонується при розрахунку трудомісткості облікових робіт розділити трудовитрати на фіксовану і динамічну складові.

Під фіксованою частиною розуміється норма часу на облікові роботи, яка є традиційною для даного підприємства, або розрахована 3 
використанням будь-якого сучасного методу оцінки трудовитрат без урахування розглянутої специфіки облікових робіт. У теперішній час для визначення фіксованої частини трудовитрат можна використовувати Міжгалузеві нормативи чисельності працівників бухгалтерського обліку, які наведені у [11].

Динамічна частина передбачає коригування оцінки трудомісткості облікових операцій, визначеної в якості фіксованої частини, 3 використанням системи коригуючих коефіцієнтів:

1) коефіцієнт впливу мінливості законодавства $\left(k_{3}\right)$ - відносна характеристика впливу можливих змін в законодавчих актах на трудомісткість облікових робіт;

2) коефіцієнт впливу нових задач $\left(k_{\mathrm{H}}\right)-$ відносна характеристика впливу новизни задач на трудомісткість облікових робіт;

3) коефіцієнт впливу організаційних змін $\left(k_{\circ}\right)$ - відносна характеристика впливу очікуваних організаційних змін в роботі облікового апарату на трудомісткість облікових робіт;

4) коефіцієнт впливу можливих помилок $\left(k_{\text {п }}\right)$ - відносна характеристика впливу ймовірного допущення помилок, які вимагатимуть виправлення, на трудомісткість облікових робіт.

Коефіцієнт впливу мінливості законодавства може бути визначений як відношення загальної кількості законодавчих та нормативних актів, які використовуються в роботі певним працівником облікового апарату, до кількості тих 3 них, які залишаються без змін, i розрахований за формулою:

$$
k_{3 i}=L_{i}^{A} / L_{i}^{F}
$$

де $k_{\text {зi }}-$ коефіцієнт впливу мінливості законодавства на трудомісткість облікових робіт $i$-го працівника облікового апарату;

$L_{i}^{A}-$ загальна кількість нормативних використовуються в обліковій роботі працівником облікового апарату;

$L_{i}^{F}$ - кількість законодавчих та нормативних актів, які використовуються в обліковій роботі $i$-м працівником облікового апарату i залишаються без змін.

Оскільки кількість законодавчих та нормативних актів, які залишаються без змін, визначається за формулою:

$$
L_{i}^{F}=L_{i}^{A}-L_{i}^{V}
$$

де $L_{i}^{V}-$ кількість законодавчих та нормативних актів, які використовуються в обліковій роботі $i$-м працівником облікового апарату і зазнали змін протягом звітного періоду, то:

$$
k_{3 i}=L_{i}^{A} /\left(L_{i}^{A}-L_{i}^{V}\right),
$$

Очевидно, що за відсутності змін в законодавчих та нормативних актах $\left(L_{i}^{V}=0\right)$ значення $k_{\text {зi }}$ буде дорівнювати одиниці, тобто вплив мінливості законодавства на трудомісткість облікових робіт даного працівника у такому випадку буде відсутній. Зміни у законодавстві приводитимуть до

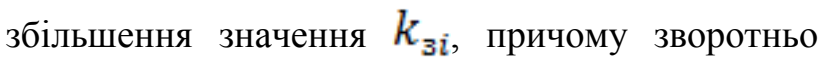
пропорційна залежність для розрахунку даного коефіцієнту запропонована у зв'язку 3 необхідністю урахування нелінійного зростання трудомісткості облікових робіт при збільшенні кількості (та, відповідно, частки) законодавчих та нормативних актів, які мають бути враховані у своїй роботі певним працівником облікового апарату, та зміни, у яких можуть бути взаємопов'язаними. Так, наприклад, при зміні протягом звітного періоду 1\% законодавчих або нормативних актів, які регламентують здійснення обліку певним працівником облікового апарату, коефіцієнт впливу мінливості законодавства становитиме 1,01, при зміні $10 \%$ о - 1,11, при зміні 50\% - 2,0, а при зміні протягом звітного періоду в усіх законодавчих та нормативних актах, які має використовувати в своїй роботі певний обліковий працівник, значення $k_{\text {зi }}$ (та, відповідно, трудомісткість роботи даного працівника) буде прагнути до нескінченності.

Коефіцієнт впливу мінливості законодавства може бути визначений для усіх облікових робіт на даному підприємстві як відношення загальної кількості законодавчих та нормативних актів, які використовуються в роботі усіма працівниками облікового апарату, до кількості тих 3 них, які залишаються без змін:

$$
k_{\mathrm{s}}=\sum_{i=1}^{n} L_{i}^{A} / \sum_{i=1}^{n} L_{i}^{F}=\sum_{i=1}^{n} L_{i}^{A} / \sum_{i=1}^{n}\left(L_{i}^{A}-L_{i}^{V}\right)
$$

де $n$ - загальна кількість працівників облікового апарату даного підприємства, або, відповідно:

$$
k_{3}=\sum_{i=1}^{n} L_{i}^{A} / \sum_{i=1}^{n}\left(L_{i}^{A}-L_{i}^{V}\right)
$$


Проте вплив мінливості законодавства не підкорятиметься правилу адитивності, оскільки зміни у певному законодавчому або нормативному документі можуть вплинути на роботу декількох (чи, навіть, усіх) працівників облікового апарату підприємства:

$$
k_{\mathrm{s}} \leq \sum_{i=1}^{n} k_{\mathrm{si}},
$$

або згідно з формулами (3)-(4):

$$
\sum_{i=1}^{n} L_{i}^{A} / \sum_{i=1}^{n}\left(L_{i}^{A}-L_{i}^{V}\right) \leq \sum_{i=1}^{n} \frac{L_{i}^{A}}{L_{i}^{A}-L_{i}^{V}}
$$

Тому більш коректним уявляється розрахунок коефіцієнту впливу мінливості законодавства для усіх облікових робіт на певному підприємстві, виходячи зі співвідношення сукупної трудомісткості облікових робіт усіх працівників облікового апарату даного підприємства 3 урахуванням та без урахування цього впливу:

$$
K_{\mathrm{s}}=\sum_{i=1}^{n}\left(k_{3 i} W_{i}\right) / \sum_{i=1}^{n} W_{i}
$$

де $K_{3}-$ коефіцієнт впливу мінливості законодавства на трудомісткість облікових робіт на даному підприємстві;

$W_{i}$ - трудомісткість облікової роботи $i$-го працівника облікового апарату, розрахована за традиційними методиками без урахування впливу змін у законодавчих та нормативних актах протягом звітного паріоду.

Аналогічним чином коефіцієнт впливу нових задач $\left(k_{\mathrm{H}}\right)$ може бути визначений як відношення загальної кількості задач, що виконує працівник, до кількості тих $з$ них, які для даного працівника не $\epsilon$ новими:

$$
k_{\mathrm{H} i}=T_{i}^{A} / T_{i}^{C}=T_{i}^{A} /\left(T_{i}^{A}-T_{i}^{N}\right),
$$

де $k_{\text {нi }}$ - коефіцієнт впливу нових задач на трудомісткість облікових робіт $i$-го працівника облікового апарату;

$T_{i}^{A}$ - загальна кількість облікових задач, які має виконувати у своїй роботі $i$-й працівник облікового апарату;

$T_{i}^{C}$ - кількість облікових задач, які має виконувати у своїй роботі $i$-й працівник облікового апарату, для якого ці задачі $\epsilon$ звичними;

$T_{i}^{N}$ - кількість нових облікових задач протягом звітного періоду для $i$-го працівника облікового апарату.

Як i для коефіцієнту впливу мінливості законодавства, значення $k_{\text {нi }}$ при відсутності нових задач для даного облікового працівника $\left(T_{i}^{N}=0\right)$ дорівнюватиме одиниці (вплив на трудомісткість облікових робіт відсутній) i нелінійного зростатиме зі збільшенням кількості (i, відповідно, частки) задач, які є новими для $i$-го працівника облікового апарату даного підприємства.

Так само аналогічно розрахунку коефіцієнту впливу мінливості законодавства для усіх облікових робіт на певному підприємстві за формулою (8), може бути розрахований i коефіцієнт впливу нових задач для усіх працівників облікового апарату на даному підприємстві:

$$
K_{\mathrm{H}}=\sum_{i=1}^{n}\left(k_{\mathrm{Hi}} W_{i}\right) / \sum_{i=1}^{n} W_{i},
$$

причому вплив нових задач на трудомісткість облікових робіт також не підкоряється правилу адитивності.

У свою чергу коефіцієнт впливу організаційних змін $\left(k_{\text {o }}\right)$ може бути визначений як відношення загальної кількості організаційних зв'язків певного працівника облікового апарату до кількості тих організаційних зв'язків, які не зазнали змін протягом звітного періоду внаслідок організаційних перетворень на підприємстві:

$$
k_{\mathrm{o} i}=C_{i}^{A} / C_{i}^{C}=C_{i}^{A} /\left(C_{i}^{A}-C_{i}^{N}\right),
$$

де $k_{\text {оi }}$ - коефіцієнт впливу організаційних змін на трудомісткість облікових робіт $i$-го працівника облікового апарату;

$C_{i}^{A}$ - загальна кількість організаційних зв'язків $i$-го працівника облікового апарату;

$C_{i}^{C}-$ кількість організаційних зв'язків $i$-го працівника облікового апарату, які залишились незмінними протягом звітного періоду;

$C_{i}^{N}-$ кількість організаційних зв'язків $i$-го працівника облікового апарату, які змінились внаслідок запровадження організаційних змін на підприємстві протягом звітного періоду.

Аналогічно коефіцієнтам, розглянутим вище, якщо певний обліковий працівник протягом 
звітного періоду не був задіяний в організаційних змінах на підприємстві $\left(C_{i}^{N}=0\right)$, значення $k_{\text {оi }}$ для нього дорівнюватиме одиниці (вплив на трудомісткість облікових робіт відсутній) 3 нелінійним зростанням при виникненні змін в організаційних зв'язках, у яких даний працівник задіяний, а коефіцієнт впливу організаційних змін на трудомісткість робіт усіх працівників облікового апарату на даному підприємстві:

$$
K_{\mathrm{o}}=\sum_{i=1}^{n}\left(k_{\mathrm{o} i} W_{i}\right) / \sum_{i=1}^{n} W_{i}
$$

Нарешті останній із запропонованих коефіцієнтів - коефіцієнт впливу можливих помилок $\left(k_{\text {п }}\right)$ - може бути визначений як сума одиниці та добутку середньозваженої кількості попередніх етапів обробки інформації для облікових задач, які виконує певний обліковий працівник, та ймовірності допущення помилок працівниками, що виконують попередні облікові операції на попередніх етапах для відповідної задачі:

$$
k_{\mathrm{mi}}=1+\sum_{t=1}^{T_{i}^{A}} \frac{E_{t i} \cdot P_{t i}}{T_{i}^{A}}
$$

де $k_{\text {пi }}-$ коефіцієнт впливу можливих помилок на трудомісткість облікових робіт $i$-го працівника облікового апарату;

$P_{t i}$ - ймовірність допущення помилок працівниками, що виконують попередні облікові операції для $t$-ї облікової задачі $i$-го працівника облікового апарату.

Ймовірність допущення помилок на попередніх облікових операціях визначається експертним шляхом у залежності від складності цих операцій та кваліфікації вказаних робітників і знаходиться в діапазоні від 0 до 1 .

Для усіх облікових робіт на певному підприємстві коефіцієнт впливу можливих помилок може бути розрахований за формулою:

$$
K_{\mathrm{n}}=\sum_{i=1}^{n}\left(k_{\mathrm{mi}} W_{i}\right) / \sum_{i=1}^{n} W_{i},
$$

На підставі запропонованих коефіцієнтів може бути визначений узагальнюючий інтегральний коефіцієнт впливу динамічної складової на трудомісткість облікових робіт:

$$
k_{\mathrm{A} i}=k_{\mathrm{si}} \cdot k_{\mathrm{H} i} \cdot k_{\mathrm{o} i} \cdot k_{\mathrm{\Pi i}},
$$

або з урахуванням виразів (3), (9), (11) та (13) коефіцієнт впливу динамічної складової на трудомісткість облікових робіт $i$-го облікового працівника становитиме:

$$
k_{\text {дi }}=\frac{L_{i}^{A} \cdot T_{i}^{A} \cdot C_{i}^{A}}{\left(L_{i}^{A}-L_{i}^{V}\right)\left(T_{i}^{A}-T_{i}^{N}\right)\left(C_{i}^{A}-C_{i}^{N}\right)}\left(1+\sum_{t=1}^{T_{i}^{A}} \frac{E_{t i} \cdot P_{t i}}{T_{i}^{A}}\right)
$$

Зрозуміло, що мінімальне значення $k_{\text {дi }}$ дорівнює 1, а значення коефіцієнту впливу динамічної складової на трудомісткість усіх облікових робіт на підприємстві визначатиметься за формулою, аналогічною формулам для окремих коефіцієнтів:

$$
K_{\mathrm{д}}=\sum_{i=1}^{n}\left(k_{\mathrm{дi}} W_{i}\right) / \sum_{i=1}^{n} W_{i},
$$

\section{Висновки i перспективи подальших} досліджень. 3 використанням запропонованого підходу до оцінки трудомісткості облікових робіт на основі розділення загальної трудомісткості на фіксовану i динамічну складові може бути здійснене оцінювання рівня трудовитрат робітників бухгалтерії в умовах реформування системи обліку та наявності непередбачуваних видів робіт.

Напрямками подальших досліджень має стати визначення груп факторів, що впливають на коефіцієнт динамічності трудовитрат та його складові, якісна та кількісна характеристика цих факторів в умовах інтегрованої і дуалістичної системи обліку.

\section{ПЕРЕЛІК ВИКОРИСТАНИХ ДЖЕРЕЛ}

1. Сокольська Р.Б. Методологічні та організаційно-методичні аспекти створення системи фінансового обліку на підприємстві / Р.Б. Сокольська // Науковий вісник Ужгородського університету. Серія «Економіка». Збірник наукових праць. - Ужгород, 2016. - Випуск 1(47). - Т.1. - С. 480 - 484.

2. Король Г.О. Оптимізація періодичності надходження інформації в системі фінансового контролю на підприємстві / Г.О. Король, Р.Б. Сокольська, В.Д. Зелікман // Економіка: проблеми теорії та практики. Збірник наукових праць. Випуск 153. - Дніпропетровськ: ДНУ, 2002. - 204 с. - С. 112 - 115.

3. Сокольська Р.Б. Методика визначення інформаційних потоків, які потребують оптимізації / Р.Б. Сокольська, С.І. Заяць, В.Д. Зелікман // Економічний вісник Національного гірничого університету. - 2004. 
- № 4(8). - C. $103-109$.

4. Багрова І.В. Нормування праці: Навчальний посібник / І.В. Багрова. - К.: Центр навчальної літератури, 2003. $-212 \mathrm{c}$.

5. Горбатюк К.В. Математичні моделі в нормуванні праці на базі теорії нечітких множин: монографія / К.В. Горбатюк. - Хмельницький: ХНУ, 2013. - 158 с.

6. Дзюба С.Г. Нормування праці в вітчизняній і міжнародній економіці. / С.Г. Дзюба, І.Ю. Гайдай. Донецьк: ТОВ «Юго-Восток, Лтд», 2005. - 172 с.

7. Бутинець Ф.Ф. Організація бухгалтерського обліку: Підручник / Ф.Ф. Бутинець, О.П. Войналович, І.Л. Томашевська; за ред. Ф. Ф. Бутинця. - Житомир: Рута, 2006. -528 с.

8. Войналович О.П. Організація бухгалтерського обліку: теоретико-методичні засади: автореф. дис. на здобуття наук. ступеня канд. екон. наук: спец. 08.06 .04 «Бухгалтерський облік, аналіз і аудит» / Войналович Олена Петрівна, Національний аграрний університет. - К., 2006. -21 с.

9. Івахненков С.В. Інформаційні технології в організації бухгалтерського обліку: історія, теорія, перспективи. Наукове видання / С.В. Івахненков. - Житомир: АСА, 2001. -416 с.

10. Кульдин С.П. Генетический подход к проблеме оценки сроков трудоемкости разработки программного обеспечения с заданными требованиями к качеству / С.П. Кульдин // Прикладная информатика. - 2010. №5(29). - C. $30-42$.

11. Міжгалузеві нормативи чисельності працівників бухгалтерського обліку, затверджені Наказом Міністерства праці та соціальної політики України від 26.09.2003 № 269 [Електронний ресурс]. - Режим доступу: // http://zakon5.rada.gov.ua/rada/show/v0269203-03.

\section{REFERENCES}

1. Sokolska R. (2016). Metodolohichni ta orhanizatsiino-metodychni aspekty stvorennia systemy finansovoho obliku na pidpryiemstvi [Methodological and Organizational-Methodical Aspects of Creating of Financial Accounting System at the Enterprise]. Naukovyi visnyk Uzhhorodskoho universytetu. Seriia «Ekonomika». Zbirnyk naukovykh prats - Scientific Bulletin of Uzhgorod University. The Series "Economics". Collection of Scientific Works, Issue 1(47), Part 1, 480 - 484 [in Ukrainian].

2. Korol G. \& Sokolska R. \& Zelikman V. (2002). Optymizatsiia periodychnosti nadkhodzhennia informatsii v systemi finansovoho kontroliu na pidpryiemstvi [Optimization of Periodicity of Information Receiption in the Financial Control System at the Enterprise]. Ekonomika: problemy teorii ta praktyky. Zbirnyk naukovykh prats - Economics: Problems of Theory and Practice. Collection of Scientific Works, Issue 153, 112 - 115 [in Ukrainian].

3. Sokolska R. \& Zaiats Ye. \& Zelikman V. (2004). Metodyka vyznachennia informatsiinykh potokiv, yaki potrebuiut optymizatsii [Methodology for Determining of Information Flows that Need to be Optimized]. Ekonomichnyi visnyk Natsionalnoho hirnychoho universytetu - Economic Bulletin of the National Mining University, Issue 4(8), 103 109 [in Ukrainian].

4. Bahrova I. (2003). Normuvannia pratsi: Navch. posibnyk [Labor Rationing: Scientific Textbook] K.: Tsentr navchalnoi literatury [in Ukrainian].

5. Horbatiuk K. (2013). Matematychni modeli v normuvanni pratsi na bazi teorii nechitkykh mnozhyn: monohrafiia [Mathematical Models in the Labor Rationing on the Basis of the Theory of Fuzzy Sets: Monograph] Khmelnytskyi: KhNU [in Ukrainian].

6. Dziuba S. \& Haidai I. (2005) Normuvannia pratsi v vitchyznianii i mizhnarodnii ekonomitsi [Labor Rationing in the Domestic and International Economy] Donetsk: TOV "Iuho-Vostok, Ltd" [in Ukrainian].

7. Butynets F. \& Voinalovych O. \& Tomashevska I. (2006) Orhanizatsiia bukhhalterskoho obliku: Pidruchnyk [Organization of Accounting: Textbook] Zhytomyr: Ruta [in Ukrainian].

8. Voinalovych O. (2006) Orhanizatsiia bukhhalterskoho obliku: teoretyko-metodychni zasady [Organizing of the Accounting Area: Theoretical and Methodical Ambush] Extended abstract of candidate's thesis K. [in Ukrainian].

9. Ivakhnenkov S. (2001). Informatsiini tekhnolohii v orhanizatsii bukhhalterskoho obliku: istoriia, teoriia, perspektyvy. Naukove vydannia [Information Technologies in the Organization of Accounting: History, Theory, Prospects. Scientific Publication] Zhytomyr: ASA [in Ukrainian].

10. Kuldin S. (2010). Geneticheskii podkhod k probleme otcenki srokov trudoemkosti razrabotki programmnogo obespecheniia s zadannymi trebovaniiami $\mathrm{k}$ kachestvu [Genetic approach to the problem of estimating the time required for the development of software with specified quality requirements] Prikladnaia informatika - Applied Informatics, Issue 5(29), 30 - 42 [in Russian].

11. Mizhhaluzevi normatyvy chyselnosti pratsivnykiv bukhhalterskoho obliku, zatverdzheni Nakazom Ministerstva pratsi ta sotsialnoi polityky Ukrainy vid 26.09.2003 № 269 [Intersectoral Norms of the Number of Employees of Bookkeeping accounting. Approved by the Order of the Ministry of Labor and Social Policy of Ukraine from 26.09.2003 \#269] (n. d.). http://zakon5.rada.gov.ua. Retrieved from: http://zakon5.rada.gov.ua/rada/show/v0269203-03 [in Ukrainian]. 